\title{
TRAVESSIA E ROTAS das Literaturas Africanas de Língua Dortuguesa (Das profecias libertárias às distopias contemporâneas)
}

Carmen Lucia Tindó secco

Primeiramente*, será discutida a importância do ensino das Literaturas Africanas em tempos de perda de utopias. Num segundo momento, será apresentado um panorama amplo do percurso dessas recentes literaturas, nascidas sob o signo das profecias libertárias, e que, hoje, vivem, também, o desencanto contemporâneo. Letras, que embora consideradas, ainda, menores pela maioria das Universidades Brasileiras, alertam, como as demais litaeraturas atuais, para o desmoronamento da Verdade, do Progresso, da Ética. O escritor moçambicano Mia Couto e o angolano José Eduardo Agualusa, por exemlo, possuem contos, cujos cenários são aeroportos, lugares em trânsito que problematizam alegoricamente o estilhaçamento identitário póscolonial. Pepetela, outro autor angolano. que em 1997 recebeu o Prêmio Camões, evidencia, com o romance O Desejo de Kianda (1995), as ruínas de uma Angola distópica, onde, parodiando Marx, "tudo que é sólido desmancha no ar".

* Aos colegas Maria Theresa Abelha Alves, Jorge de Souza Araújo, Jorge Fernandes da Silveira, Valdete Pinheiro Santos e Gilda da Conceição Santos, que lutaram pela criação do Setor de Literaturas Africanas de Língua Portuguesa na UFRJ e aos Organizadores deste V Congresso da UEFS, que deram espaço de destaque neste evento a essas literaturas, ofereço meu texto e um moçambicano obrigada: Kanimambo!

$\mathrm{E}$, antes de iniciar, cumprimento os presentes com uma saudação portuguesa, ainda muito usada em Angola: Bem Haja! 


\section{REFLEXÕES ACERCA DA IMPORTÂNCIA DO ENSINO DAS LITERATURAS AFRICANAS}

O Neoliberalismo, como diz o geógrafo brasileiro Milton Santos, no livro Fim de Século e Globalização, não trouxe mudanças significativas à melhoria da sociedade, ou seja, à resolução das grandes desigualdades sociais e econômicas. De acordo com esse autor, hoje, o que é federativo ao nível mundial não é uma vontade de liberdade, mas de dominação; não é o desejo de cooperação, mas de competição, tudo exigindo um rígido esquema de organização que atravessa todas as relações da vida humana.

Com tais signos, o que globaliza falsifica, corrompe, desequilibra, destrói. Vivemos um mundo da mídia, um mundo como fábrica de engano, simulacro do que deveria ser, mas que existe, apenas, como realidade virtual. O que, no entanto, continua imperando são os ditames do Fundo Monetário Internacional que organiza as regras da economia para os chamados "países em desenvolvimento" como, por exemplo, o Brasil, o Peru, Angola, Moçambique, entre outros.

A era do globalismo dispersa, fragmenta, estilhaça corpos e desejos, reduz as utopias libertárias, aposta na internacionalização do consumo e, ao mesmo tempo, faz do ser humano um passageiro do efêmero.

Ao preparar os quadros profissionais de seus países, as Universidades devem incentivar a articulação entre suas culturas tradicionais e os novos paradigmas que se impõem. E para que estes não afetem os sentidos humanos e cósmicos essenciais, a Literatura, ao lado da História e da Filosofia, se apresenta como uma das disciplinas fundamentais, porque contribui significativamente para que o lado poético da existência não se perca. Essa é a posição de Octavio Paz, que reflete sobre as relações entre poesia, história e vida: "A interrogação a respeito das possibilidades de encarnação da poesia não é uma pergunta sobre o poema e, sim, sobre a História: será uma quimera pensar em uma sociedade que reconcilie o poema e o ato, que seja palavra viva e vivida?" (Paz, 1972: 95)

Em seu livro Labirinto da Solidão, o referido escritor mexicano alerta para o fato de que a situação do México "não é muito diversa da de outros países da América Latina e da África” (Paz, 1984: 170). Segundo ele, o impacto social de modernas tecnologias, impostas pelas potências estrangeiras que controlam a indústria eletrônica da mídia, gera, na maioria dos países pertencentes a esses continentes, novas formas de opressão, excluindo do processo produtivo aqueles que não têm acesso à linguagem da informática. Complexos e caros computadores imprimem uma velocidade 
e uma dinâmica incompatíveis com o modo de pensar da grande parcela da população dessas nações. Um contraste chocante se estabelece pelo confronto da miséria de muitos países da África e da América Latina diante dos sofisticados códigos e aparelhos importados. Aprisionados a uma economia interplanetária e multinacional, esses países se tornam, cada vez mais, periféricos, girando em torno das grandes potências.

Com a queda do Muro de Berlim e a chamada "crise das utopias", houve um apagamento de antigos paradigmas ideológicos. As figuras dos líderes revolucionários foram esmaecidas. Os heróis das vanguardas políticas, dos movimentos de libertação popular que, nos anos 60, se apresentavam como personagens singulares construtoras da história, cederam lugar às corporações anônimas, às grandes empresas de redes internacionais, nas quais, geralmente, o individual se dissolve no coletivo e o nacional se transnacionaliza. $\mathrm{Na}$ nova conjuntura globalizante, os grandes temas, as grandes causas têm seus sentidos esvaziados. O esfacelamento das "verdades", da ética, da liberdade provoca a dormência dos valores morais. A comunicação, embora se tenha utilizado de modernas linguagens, se torna oca, porque opera com simulacros (Chauí, 1991: 6). Tanta tecnologia foi imposta, que não houve tempo de ser absorvida. As grandes potências, saturadas das inovações da informática, jogaram seus produtos nos mercados dos países periféricos. Houve, desse modo, uma hipertrofia da memória nessas sociedades, pois os cérebros eletrônicos ficaram com o encargo de armazenarem tudo.

Com a crise no Leste Europeu, ocorreram mudanças geo-políticas mundiais. O mercado contemporâneo passou a ser regido por blocos econômicos interplanetários que manipulam a economia dos países dependentes, impedindo neles as iniciativas genuinamente nacionais. O controle das novas tecnologias acirra, no panorama atual, seja na América Latina ou na África, as distâncias entre o que podemos chamar "o novo colonialismo". Quem detém os saberes informatizados, sua linguagem, exerce, hoje, o domínio no campo político-cultural. Essa é a nova divisão de trabalho que substitui o modelo taylorista do final do século XIX. A indústria da informática foi imposta às elites dos países do Terceiro Mundo, enquanto a maioria da população dessas nações não pode se beneficiar desse processo de informatização.

A América Latina e a África, com suas múltiplas faces culturais, prenhes de tradições e mitos, podem ainda impor suas respectivas presenças no cenário mundial, se resgatarem suas diferenças, empreendendo uma luta, através de palavras e ações, contra alguns dos cânones globais impostos pelo neoliberalismo no campo cultural. Homi Bhabha e Edward Said, teóricos atuais dos tempos pós-coloniais, defendem que identidades puras são inexistentes e, por tal razão, postulam a valorização das heterogeneidades, ou seja, o 
contato entre as culturas, o diálogo das diferenças, a volta crítica ao passado. Segundo esses críticos, a diferença não pode ser tratada como elemento monológico e exótico, mas deve ser pensada de modo dialógico. Tanto a África, como a América Latina se constituem de pluralismos culturais que devem ser respeitados e concebidos sempre de forma interativa. Para terem acesso a uma maior projeção política no mundo contemporâneo, entre outras medidas, devem afirmar, através da valorização do multiculturalismo, a construção de suas próprias identidades, evitando, assim, se tornarem meras estatísticas periféricas em programas de software. Dentro de tal perspectiva, Bhabha e Said postulam uma nova eticidade política a ser engendrada pelo viés do multiculturalismo para que tanto a África, como a América Latina se reconstruam e afirmem as diversas especificidades de seus respectivos imaginários sociais mesclados pelo contato, através dos séculos, com culturas várias. Essa nova eticidade pode ser alcançada por intermédio da literatura e, em especial, de uma poesia tecida por um discurso que, recuperando as tradições e a memória histórica, seja, como Octavio Paz propôs, um liame constante entre a imaginação poética e a realidade vivida.

No livro A Outra Voz, Octavio Paz fez o inventário das ruínas da época moderna, analisando o embate da poesia com as exigências de um tempo que nega o futuro e que exalta apenas o agora. Após discutir os efeitos da publicidade e das novas tecnologias sobre a linguagem poética, pergunta: "Qual o lugar da poesia nos anos que vêm pela frente?" (Paz, 1993: 145). Sua preocupação é com a sobrevivência da humanidade e da arte; defende a poesia como a "outra voz", ou seja, o discurso que não deixará morrer as subjetivas emoções caracterizadoras do ser humano. O ensaísta e poeta mexicano defende que só ao arte é capaz de exercitar a imaginação, pois é "antídoto da técnica e do mercado". Exalta a necessidade de se conhecer o passado para reavaliá-lo. Uma cultura que perde a memória se afasta de si própria. É essa também a opinião de Edward Said, para quem

a invocação do passado constitui uma das estratégias mais comuns nas interpretações do presente. O que inspira tais apelos não é apenas a divergência quanto ao que ocorreu no passado e o que teria esse passado, mas também a incerteza se o passado é de fato passado, morto e enterrado, ou se persiste, mesmo que talvez sob outras formas. (Said, 1995: 11)

É com essa consciência que um Professor de Literaturas Africanas deve se posicionar, hoje, observando que o quadro de discriminações e anulação da alteridade e das diferenças em relação à África se mostra ainda mais cruel, pois elimina as polaridades estruturadoras dos paradigmas ideológicos que nortearam as décadas de 50, 
60 e 70 de nosso século. O capitalismo neoliberal, assentado na prática do livre mercado, acentua a riqueza de poucos e exacerba a miséria de muitos.

Diante desse quadro político tão drástico, resta, no entanto, a meu ver, o trabalho com uma das poucas utopias ainda possíveis: a da escritura literária, já que esta aponta para camadas profundas do imagináio cultural e social, possibilitando uma leitura crítica da realidade.

\section{SONHOS, PROFECIAS E DISTOPIAS NAS LITERATURAS AFRICANAS DE LÍNGUA PORTUGUESA: UMA TRAVESSIA NO TEMPO}

As Literaturas Africanas de Língua Portuguesa são ainda jovens, com aproximadamente, 150 anos de existência. Apesar de os primeiros textos datarem da segunda metade do século XIX, só no século XX, na década de 30 em Cabo Verde (com Claridade), e nos anos 50 em Angola (com Mensagem), é que essas literaturas começaram a adquirir maioridade, se descolando da literatura portuguesa trazida como paradigma pelos colonizadores. Embora não se tenham desenvolvido sempre em conjunto, devido aos seus respectivos contextos sócio-culturais diferenciados, essas literaturas são, geralmente, estudadas, nos meios universitários ocidentais, sob denominação abrangente que envolve a produção literária de Angola, Moçambique, Cabo Verde, Guiné-Bissau, São Tomé e Príncipe, ex-colônias de Portugal na África.

Tal designação se deve à relevância que as literaturas africanas tiveram, nas décadas de 40, 50 e 60 do nosso século, quando, reunidos na Casa dos Estudantes do Império de Lisboa, estudantes africanos - entre eles Agostinho Neto, Amílcar Cabral, Eduardo Mondlane, Mário Pinto de Andrade, Francisco José Tenreiro, António Jacinto - iniciaram, sob os ecos da negritude francesa, do negrismo afro-americano e sob o signo do anticolonialismo, um movimento político-literário de valorização das literaturas de seus países. Nesse processo, além da negritude, cuja influência levou à defesa da africanidade no campo literário, tiveram também importância o Neo-Realismo português e o Modernismo brasileiro por seus conteúdos sociais que serviram de modelo à fundação do nacionalismo nessas literaturas.

Em Angola e Moçambique, nos anos 50, surge uma poesia direcionada para a afirmação das raízes africanas e da identidade a ser recuperada. Sob o lema "Vamos descobrir Angola", o Movimento dos Novos Intelectuais de Angola propunha o resgate da angolanidade, também reivindicada pelos poetas de Mensagem, entre eles 
Viriato Cruz, António Jacinto, Agostinho Neto, autor do livro de poemas Sagrada Esperança, de quem lembramos o poema:

\section{MÃos esculturais}

Além deste olhar vencido cheio de mares negreiros fatigado e das cadeias aterradoras que envolvem lares além do silhuetar mágico das figuras nocturnas após cansaços em outros continentes dentro de África

Além desta África de mosquitos e feitiços sentinelas de almas negras mistério orlado de sorrisos brancos adentro das caridades que exploram e das medicinas que matam

Além África dos atrasos seculares em corações tristes

Eu vejo as mãos esculturais dum povo eternizado nos mitos inventados nas terras áridas da dominação as mãos esculturais dum povo que constrói sob o peso do que fabrica para se destruir Eu vejo além África amor brotando virgem em cada boca em lianas invencíveis da vida espontânea e as mãos esculturais entre si ligadas contra as catadupas demolidoras do antigo

Além deste cansaço em outros continentes a África viva sinto-a nas mãos esculturais dos fortes que são povo e rosas e pão e futuro. 
Em Moçambique, também nessa época, se inicia uma poética voltada para a moçambicanidade, cujas principais vozes foram as de Noêmia de Souza, Marcelino dos Santos e José Craveirinha, poeta que, em 1992, recebeu o Prêmio Camões de Literatura, e continua a escrever até hoje, tendo passado por várias fases. O seu livro Xigubo (1964) reúne poemas desse período, versando sobre temas africanos e fazendo a crítica ao racismo, ao colonialismo, aos séculos de escravidão. Citamos do poeta o poema inédito (cedido pela Dra. Fátima Mendonça, Prof ${ }^{a}$ da Universidade Eduardo Mondlane, de Maputo):

SAMBO

Do mar

Vieram os lívidos navegantes

com espadas e missangas

e ficaram.

O cheiro da pólvora e do sangue chamou os corvos

e as quizumbas de dentes amarelos

comeram da guerra das espadas

do erotismo das balas

e do rútilo brilho das missangas.

E para um Brasil de roças de cacau

senhores de engenho

gritos de cangaceiro

e minas de oiro

as proas dos barcos levaram Sambo

os batuques de Sambo

e a mais linda filha de Sambo.

E o negro

aprendeu as rezas dos capitães negreiros

dizendo o terço com grilhetas nos pulsos e nos pés

e o Brasil se encontrou.

Sambo das roças brasileiras

das tardes de futebol no Maracanã

do candomblé na Bahia

e das escolas de samba nas favelas do morro

volta que os cajueiros estão florindo em África

e os corvos e as quizumbas de Johannes Strijdon 
ansiosamente querem

mais carnavais de sangue.

Em Angola, a poesia de Agostinho Neto, por exemplo, em sua fase da negritude, também clamou contra a opressão sofrida pelos negros, denunciando a exploração escrava. Tanto em Angola, como em Moçambique, nesse período, a poesia se afasta dos cânones portugueses e recusa a civilização européia. É uma poética acusatória, de forte impacto social, que faz ecoar o grito negro da rebeldia. Em busca das raízes profundas do ser africano, utiliza vocábulos das línguas nativas, de modo a macular o idioma do colonizador. Craveirinha, por exemplo, traz para seus poemas os sons das marimbas e do tambor, mesclando o português com palavras em ronga. Poetas angolanos desse momento também procedem assim, introjetando ao português expressões do quimbundo, do mbunda, do quicongo e de outras línguas, de modo a assinalar, com odores e saberes africanos, o idioma trazido pelo colonizador.

Representando a poesia de São Tomé e Príncipe dessa época, temos as vozes de Francisco José Tenreiro, de Maria Manuela Margarido e de Alda do Espírito Santo, entre outras, defendendo os paradigmas da negritude e/ou a identidade das ilhas. Com a palavra, Dona Alda, uma das " grandes damas" das Literaturas Africanas:

\section{EM TORNO DA MINHA BAÍA}

Aqui, na areia,

Sentada à beira do cais da minha baía

do cais simbólico, dos fardos,

das malas e da chuva

caindo em torrente

sobre o cais desmantelado,

caindo em ruínas

eu queria ver à volta de mim, nesta hora morna do entardecer

no mormaço tropical

desta terra de África

à beira do cais a desfazer-se em ruínas, abrigados por um toldo movediço uma legião de cabecinhas pequenas, à roda de mim, num vôo magistral em torno do mundo desenhando na areia 
a senda de todos os destinos

pintando na grande tela da vida

uma história bela

para os homens de todas as terras

ciciando em coro, canções melodiosas

numa toada universal

num cortejo gigante de humana poesia

na mais bela de todas as lições:

HuMANIDADE.

(in Poetas de São Tomé e Príncipe, 1963. Apud No Reino de Caliban II, p. 449 e 450)

Em Cabo Verde, desde a década de 30, a revista Claridade, fundada em 1936, clamava por uma poesia autêntica, que buscava afirmar a cabo-verdianidade. Essa poética, ao contrário do que ocorre em Moçambique e Angola, na década de 50, não reivindicava os temas da negritude, tendo em vista a predominância mestiça em Cabo Verde, cujas ilhas, desertas na ocasião da descoberta, foram povoadas por portugueses oriundos da Madeira e negros vindos da Guiné.

Claridade representou uma virada na lírica do Arquipélago. Influenciada pelo Modernismo brasileiro, essa geração rompeu com as formas clássicas da poesia, incorporando o verso livre, a não preocupação com as rimas, o uso do crioulo, os temas cabo-verdianos. Ouçamos Jorge Barbosa, uma das mais representativas vozes de Claridade:

O MAR

Ai o mar que nos dilata sonhos e nos sufoca desejos!

- Ai a cinta do mar que detém ímpetos ao nosso arrebatamento e insinua horizontes para lá do nosso isolamento!

(Convite da viagem apetecida que se não faz.)

- Ai o cântico estranho 
do Atlântico,

que se não cala em nós!

Talvez um dia

inesperado remoinho de águas

passe

borbulhante,

envolvente,

alguma onda mais alta

se levante...

Talvez um dia...

— Quem sabe!...

Depois

na senda dos tempos

continuará

a marcha dos séculos

... E outra lenda

virá...

(Apud: Mario Pinto de Andrade, op. cit., p. 19 e p. 20)

A poética claridosa fez o testemunho documental do dilema crucial do ilhéu, um ser cindido pelo desejo de ficar e pela necessidade de partir. Falta, entretanto, à maioria dos representantes dessa lírica uma conotação político-social mais direta, o que só ocorrerá efetivamente com as gerações seguintes. Seus principais poetas foram Jorge Barbosa, Manuel Lopes, Oswaldo Alcântara (pseudônimo, como poeta, de Baltasar Lopes). Os dois últimos também escreveram prosa: Manuel Lopes, Um Galo Cantou na Baía (contos) e Os Flagelados do Vento Leste (romance); Baltasar Lopes, Chiquinho (romance). Tais narrativas, de cunho social, assemelham-se ao nosso regionalismo de 30, em particular aos romances de José Lins do Rego e Graciliano Ramos.

Só em 1944, a geração Certeza trouxe um tom marxista às narrativas de Cabo Verde. Orlanda Amarílis, que continua a escrever até hoje, foi uma das principais representantes, trazendo para seus contos o imaginário feminino das ilhas.

Nos anos 60, com a guerra declarada contra o colonialismo português, unem-se as literaturas das cinco colônias portuguesas na África em torno da temática libertária, cujas utopias fazem dos versos armas de luta contra o salazarismo português. Em 
Cabo Verde, Amílcar Cabral lidera o PAIGC, o poeta Ovídio Martins proclama "o ficar para resistir", outros poetas se destacam: Osvaldo Osório, Armênio Vieira, Tomé Varela.

Outro importante poeta cabo-verdiano, cuja produção se inicia em 1959 e entra pelos anos 80, é Corsino Fortes. Sua obra, Pão \& Fonema (1974) e Árvore \& Tambor (1986), representa um salto em direção a uma linguagem comprometida com o universo ilhéu, pois busca reescrever Cabo Verde com tintas próprias, com o ritmo dos tambores e fonemas crioulos. Sua poesia apresenta alto grau de consciência técnica e política. Prima pelo rigor formal e contenção da linguagem, lembrando a poética de João Cabral. Com a palavra Corsino, no poema "De boca a barlavento":

I

Esta

a minha mão de milho \& marulho

Este

o sol a gema E não

o esboroar do osso na bigorna

E embora

O deserto abocanhe a minha carne de homem

E caranguejos devorem

esta mão de semear

Há sempre

Pela artéria do meu sangue que $g$

$\mathrm{O}$

$\mathrm{t}$

e

j

a

De comarca em comarca

A árvore E o arbusto

Que arrastam

As vogais e os ditongos

para dentro das violas

II

Poeta! todo o poema:

geometria de sangue \& fonema

Escuto Escuta 
Um pilão fala
árvores de fruto
ao meio do dia
E tambores
erguem
na colina
Um coração de terra batida
E lon longe
Do marulho à viola fria
Reconheço o bemol
Da mão doméstica
Que solfeja
Mar \& monção mar \& matrimónio
Pão pedra palmo de terra
Pão \& patrimómio

Pão \& fonema, 1974 (apud No Reino de Caliban I, p. 203-4)

$\mathrm{Na}$ Guiné-Bissau, surgem nomes importantes na poesia: Vasco Cabral, Hélder Proença, entre outros. É publicada a primeira antologia da Guiné: Mantenhas para quem luta!, cujas poesias guerrilheiras cantam o desejo e o sonho de libertação.

Nessa época, em Moçambique, são editados vários fascículos sob a denominação Poesia de Combate. Na prosa moçambicana, escritores como Orlando Mendes, com o romance Portagem, e Luís Bernardo Honwana, com o livro de contos Nós Matamos o Cão-Tinhoso, denunciam a opressão e a miséria vividas pelo povo.

São muitos os poetas também em Angola a produzirem poemas nessa dicção: Costa Andrade, Jofre Rocha, e outros. Na ficção, diversos escritores optaram pela temática da guerra e pela denúncia das carências sociais. Luandino Vieira, desde os anos 60 e passando pelas décadas subseqüentes, envereda por esse caminho, mas se afirma também por um estilo próprio que busca, à maneira de Guimarães Rosa, recriar a língua de colonização, "quimbundizando-a" pela opção de transcriar a fala dos habitantes dos musseques, isto é, as favelas de Luanda, onde o povo oprimido vivia em condições subumanas. Outros escritores desse período também se destacam, entre eles Pepetela, com o seu famoso romance Mayombe, o qual, ultrapassando a dimensão apenas ideológica das narrativas comprometidas com a utopia da Revolução, discute valores humanos universais, como o amor, o sexo e a amizade, além de criticar o tribalismo e as contradições da própria guerra. Pepetela é um dos grandes escritores angolanos, cuja obra apresenta várias fases, na medida em que continua a escrever até hoje. 
Nos fins dos 60 e início dos 70 , com a intensa repressão da PIDE ( polícia salazarista), a literatura se torna bastante metafórica para driblar a censura. A poesia, principalmente em Angola e Moçambique, se torna elaborada, voltando-se sobre ela mesma. É a fase da "Poesia do Gueto", do grupo Caliban, em Moçambique, com poetas como Rui Knopfli, Sebastião Alba, Alberto de Lacerda, entre outros, e, em Angola, com poetas como David Mestre, Manuel Rui, Arlindo Barbeitos, Ruy Duarte de Carvalho, para citar somente alguns.

Com a independência, retornam as utopias. São vários os poetas a celebrarem a liberdade conquistada. Em Angola, lembramos o nome de Manuel Rui com seu livro Cinco vez̧es onz̧e: poemas em novembro, obra literariamente muito bem construída. Em Moçambique, citamos o livro Monção, de Luís Carlos Patraquim, que celebra os bons ventos libertários.

Entretanto, logo a seguir à Independência, inicia-se uma guerra de desestabilização, em Angola e Moçambique, entre os partidos que assumiram o poder e os partidos de oposição. O fim dos 80 e os 90 são marcados por um desencanto na esfera social, que se reflete na área literária. A poesia dessas décadas se caracteriza pela superação da poética "cantalutista" e pelo desaparecimento das referências circunstanciais presentes na poesia revolucionária. Há a radicalização do projeto de recuperação da língua literária, aproveitada em suas virtudes intrínsecas e universais, sem os regionalismos característicos da literatura dos anos anteriores. Há a metaconsciência e o traço crítico, mas sem o panfletarismo ideológico. Ironia, paródia, desencanto são procedimentos de denúncia à corrupção e às contradições do poder. Dialogando com poetas das gerações anteriores, essa lírica aponta para a crise das utopias e funda um novo lirismo que procura cantar os sentimentos existenciais, desvinculados do canto coletivo social. Há uma intensificação poética, através da depuração da linguagem literária que, em alguns poetas, se manifesta por experimentalismos, por corporizações plásticas de palavras, por metáforas surrealistas, por jogos verbais que acentuam a relação entre a perda da ética e a busca de uma nova estética.

Afinados a essa nova dicção, em Angola, os principais poetas atuais são João Melo, Lopito Feijóo, João Maimona, Ana Paula Tavares, Eduardo Boavena, José Luís Mendonça, de quem citamos o poema "Eu queria abster-me":

Eu queria abster-me

de olhar as lentas

feras madrugadas

paridas entre a unha e a polpa

dos meus dedos de sangue.

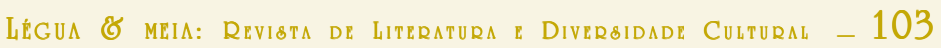


Bem queria abster-me

disso mas elas vêm

de raivas uivando implorando

cheias

da sua incompreensão do além-mar.

Bem queria abster-me

mas mexe em mim a dor

de todo o acontecer

no seio do deus transformador:

- eu sou a sua inteira compreensão

e absorvo a múltipla realidade.

(apud Letras \& Letras, 1993)

Em Moçambique, lembramos os nomes de Luís Carlos Patraquim, de Eduardo White, poeta este oriundo da revista Charrua [ palavra da língua portuguesa que significa arado, metaforizando, pois, uma renovação no chão da poesia que se fazia nos tempos revolucionários], de Armando Artur, de Nélson Saúte, entre outros. Do último, lembramos o poema:
MULHER DE M'SIRO
O m'siro
encantamento dos meus olhos
perfaz a tua insular imagem.
No litoral do teu corpo
a apoteótica espuma
do orgasmo das ondas.
Ó júbilo na falésia do canto.

(apud A Ilha de Moçambique pela Voz dos Poetas, 1992, p. 123)

Em São Tomé, não poderíamos esquecer de mencionar Conceição Lima, que faz uma poesia de revisão crítica da história de seu país, como podemos observar em seu poema a seguir:

ANTES DO POEMA

Não dispomos ainda das palavras

Que cavarão o verso oco dos dias

não dispomos ainda da idéia exacta certeira 
que amanhecerá o verso sobre o rosto

açoitado

da Cidade

Fermentem no chão as palavras os sentidos

a ideia

e escorram fogo e lava pelo corpo da

Cidade

enquanto imerso aguarda o poema o

momento profundo da floração

Não repovoarei as sombras

os lugares vazios que ficaram

Não nutrirei as lágrimas

a orla desértica das praias ensanguentadas

Não chorarei em vão

sobre o leito das águas esquecidas

As sombras regressarão às paisagens

adormecidas

adornadas de estranhas nuvens e de lianas

as lágrimas germinarão frutos

sobre a superfície agreste dos caminhos

e o choro no ventre claro

das águas redimidas

o grito poisará então sobre a madrugada

será pranto será asa será canto

para florir no crepúsculo da incerteza

como rosas como rios como asas

(apud Revista Tchiloli, Ano I, $\mathrm{n}^{\circ}$ 0, fevereiro de 97, p. 11)

A poética das asas é uma constante na poesia moçambicana pós-colonial. A poesia de Eduardo White se constrói, justamente, nessa direção: procurando a "ciência de voar e a engenharia de ser ave":

(...) o meu chão, a minha terra, traz-me sonhos terríveis e muito sangue a escorrer e demasiada ambição e se escrevo com uma certa brandura é porque pronuncio as palavras já com medo de as matar e eu quero-as vivendo e iluminadas de fascínio. Voar 
é não deixar morrer a música, a beleza, o mundo e é também fazer por escrever tudo isso. Nada pode ser mais deslumbrante que esta relação com a vida e por essa razão me obstinam as aves e me esforço por querer sê-las. (White, 1992: 29)

Na Guiné-Bissau, a mais pobre das ex-colônias, também algumas vozes novas surgem, entre as quais as de Domingas Samy e Carlos Lopes, embora, na maior parte das vezes, as narrativas ainda circulem apenas oralmente. $\mathrm{Na}$ poesia, nesses tempos de distopia, há, por exemplo, o canto lúcido do poeta António Soares Lopes Júnior, conhecido pelo pseudônimo Tony Tcheka:

\section{TECTO DE SILÊNCIO}

Ergo a minha voz

e firo o tecto do silêncio

Nego a morte de crianças

porque há míngua de medicamentos

$\mathrm{Na}$ angústia

liberto o verbo

mordo o pólo da desgraça

que grassa

nesta África desventurada

em obra

e graça

subdesenvolvendo-se

Coloco andaimes

nos alicerces do tempo

perscruto os ventos

circunciso as ondas

nego a convivência da paciência

que amordaça a fala

e cala o sentimento.

Exorcizo o paludismo

apeio a poliomielite

amputo a desgraça

e eis a graça da criança

florescendo a vida

Bissau, 1990

(apud Noites de Insónia na Terra Adormecida, 1996. p. 125) 
Em Cabo Verde, no ano de 1991, a publicação de Mirabilis: de veias ao sol, antologia organizada por José Luís Hopffer Almada, reúne os "novíssimos poetas de Cabo Verde", divulgando a poesia cabo-verdiana produzida após o 25 de Abril. O não cumprimento das promessas sociais gera um desalento. Entretanto, lembrando-se de que, mesmo no deserto, cresce a mirabilis, a nova geração resiste poeticamente a esses anos de "mau tempo literário". Destacam-se entre os mirabílicos: Manuel Delgado, David Hopffer Almada, Kaliosto Fidalgo, Euricles Rodrigues, Vera Duarte, Luís Tolentino, Vasco Martins, Canabrava, entre outros. Desse último, destacamos o poema:

PÃO E SUOR

I

De sol-a-sol

Espigam no teu rosto

Moléculas de suor

Já nos caminhos

Da África

América

Europa

Tua partida foi necessária

$\mathrm{Na}$ conjugação das coisas

Num dualismo constante

De vida \& lida

O teu corpo

Singrou mares de todos os Oceanos

Horizontes de toda a esperança...

De porto a porto

Crescem sílabas na saliva da boca

E revive no teu rosto

A cicatriz da saudade

$\mathrm{Na}$ têmpera de catabolismos

Trazes nas páginas da vida

Lágrimas salgadas da partida

Regresso

Terra amor-mãe-cretcheu 
Amargura-tristeza-saudade

(São sentimentos esquecidos)

Que confluem

Em ambiente

De festa \& alegria

E já crescem sílabas na boca

Ao molhar a palavra

Pelo canal da garganta

Saboreando o grogue de terra!

II

De sol-a-sol

Estampam no teu rosto

Moléculas de suor

Não há lágrimas que não encham

A fonte da tua nostalgia!

Pitagoricamente

Teorias + teoremas

Pão \& suor

Razão \& resistência + certeza

— Não há pão que não custa suor

Não há suor que não custa sacrifícios

E

Enquanto as enxadas

Sucumbem à estiagem

Sacrifícios nossos continuarão

E

Suor \& certeza

Espigarão no teu rosto

Procriando o pão!

1983

(Canabrava, apud Mirabilis de Veias ao Sol, p. 95-96) 
$\mathrm{Na}$ prosa, tendências variadas se apresentam no pós-independência. Há escritores que buscam a dicção do humor, fazendo a crítica da realidade. Citamos, em Angola, Uanhenga Xitu, com "Estórias na Sanzala ( Kabitu)”; Manuel Rui, com Quem me Dera Ser Onda; Pepetela, com O Cão e os Caluandas, entre outros.

Há também as obras que trabalham na linha da ficção e da história, recuperando procedimentos da oralidade e tradição africanas, em conjugação com uma escrita que utiliza procedimentos ficcionais bastante modernos. É o caso, em Angola, de Boaventura Cardoso, com Dizanga dia Muenbu; de Luandino Vieira, com Nós, os de Makulusu, entre outros livros; de Agualusa, com A Conjura, Nação Crioula, A Estação das Chuvas; de Pepetela, com Lueji, A Geração da Utopia, O Desejo de Kianda, A Parábola do Cágado Velho, romances através dos quais o escritor denuncia as guerras sempre presentes na história angolana, chamando atenção, nos três últimos livros (publicados nos anos 90), para as guerrilhas entre o MPLA e a UNITA que desestabilizaram o processo de independência e transformaram as utopias revolucionárias em distópicas ruínas, cujos destroços assinalam o dilaceramento atual de Angola.

Em Moçambique, os escritores também evidenciam a crise que atravessa o país destruído por quase trinta anos de guerra. Mia Couto, com seus romances, Terra Sonâmbula e $A$ Varanda do Frangipani, e Ba Ka Khosa, com Ualalapi, repensam a história moçambicana a partir de um trabalho arqueológico com os fantasmas da memória presentes no imaginário do país.

Em Cabo Verde, não poderíamos deixar de mencionar, na ficção, nomes como os de Teixeira de Sousa, com vários romances publicados; de Manuel Veiga, que escreve em crioulo; de Vasco Martins; de Dina Salústio e de Germano Almeida, cujo livro O Testamento do Sr. Napomuceno foi transformado em filme, em razão do sucesso que fez, ao captar, com humor e acuidade, os problemas do universo cabo-verdiano. Sintetizando, recordamos os paradigmas que norteiam o percurso das Literaturas Africanas de Língua Portuguesa: o referente às origens (segunda metade do século XIX), cujos poemas se encontram colados à produção literária portuguesa; o relativo a uma fase intermediária de busca de identidade local (primeiras décadas do século $\mathrm{XX}$ ), em que as obras são ainda perpassadas por uma ambigüidade entre a pátria lusitana e a mátria africana; o que compreende o período de mergulho nas raízes africanas e de afirmação das respectivas identidades (década de 30, em Cabo Verde, e década de 50 em Angola, Moçambique, São Tomé ); o correspondente à época das utopias libertárias, das lutas contra o colonialismo (década de 60); o que se refere à 
fase de "gueto", período de intensa censura, em que, por terem muitos escritores sido presos, a poesia, apenas metaforicamente, faz alusões ao social, abordando temas universais e voltando-se para a sua própria construção e linguagem (fim dos 60 e primeiros anos da década de 70); o que compreede os anos da pré e da pós-independência, quando voltam os temas sociais, as utopias revolucionárias, os textos celebratórios da liberdade; nessa época, surgem também narrativas que discutem a necessidade da reconstrução nacional ( década de 70), e, por fim, o que corresponde à fase atual de desencanto (anos 80 e 90), em que a literatura reflete sobre a falência dos ideais do marxismo ortodoxo e aposta na resistência cultural, investindo na recuperação dos mitos e sonhos submersos no inconsciente coletivo desses povos.

Atualmente, embora se viva o desencanto em relação a essas utopias, é urgente resgatar textos que despertaram o desejo de sonhar e repensar a realidade. É necessário construir novas utopias, nem que sejam "utopias do efêmero e do fugaz".

O ensaísta português Boaventura de Sousa Santos, em seu livro Pela mão de Alice, no qual analisa o social e o político no contexto contemporâneo, mostra que, hoje, não é fácil defender a utopia; entretanto, ele o faz, não de forma romântica, mas propondo um pensamento utópico como estratégia para impedir a estagnação cultural: "Penso que só há uma solução: a utopia. A utopia é a exploração de novas possibilidades e vontades humanas, por via da oposição da imaginação à necessidade do que existe, só porque existe, em nome de algo radicalmente melhor que a humanidade tem direito de desejar e por que merece a pena lutar." (Santos, 1996: 323)

Também, para Octavio Paz, a utopia e o sonho não devem estar nunca desvinculados da crítica, pois esta "é a aprendizagem da imaginação, é a imaginação curada da fantasia e decidida a enfrentar a realidade do mundo. A crítica nos diz que devemos aprender a dissolver os ídolos: aprender a dissolvê-los dentro de nós mesmos. Temos de aprender a ser ar, sonho em liberdade.” (Paz, 1984: 261)

É característica da linguagem poética seu caráter utópico-imaginativo e sua função revolucionária. Segundo Habermas, a linguagem literária "cola-se à pele do real não para capitular diante dele, mas para dissolvê-lo por dentro" (Habermas, 1980: 34). Desta forma, é a literatura, portanto, um dos elementos de resistência que, ao liberar a imaginação, faz os homens sonharem e questionarem, pois, conforme alertou Mia Couto, em seu livro Cronicando, "afinal de contas, quem imagina é porque não se conforma com o real estado da realidade" (Couto, 1991: 21).

\section{Sox}




\section{REFERÊNCIAS BIBLIOGRÁFIA}

ANDRADE, Mário Pinto de. Antologia temática da poesia africana. Lisboa: Livraria Sá da Costa, 1975, v.I (Na Noite Grávida de Punhais) e v.II (Canto Armado).

ANTOLOGLA poética da Guiné-Bissau. Lisboa:Inquérito,1990.

ARAÚJO, Cremilda Medina. Sonha mamana África. São Paulo: Ed. Epopéia, 1987.

BACHELARD, Gaston. A Poética do espaço. Rio: Livraria Eldorado, s. d.

BACHELARD, Gaston. O Direito de sonhar. 2. ed. SP: DIFEL, 1986.

BACHELARD, Gaston. A Água e os sonhos. SP : Martins Fontes, 1989.

BACHELARD, Gaston. O Ar e os sonhos. SP : Martins Fontes, 1990.

BHABHA, Homi. A Questão do "outro": diferença, discriminação e o discurso do colonialismo. In: HOLLANDA, Heloísa Buarque de. Pós-modernismo e política. Rio de Janeiro: Ed. Rocco, 1992.

BENDER, Gerald. Angola sob o dominio português: mito e realidade. Lisboa: Dom Quixote, 1989.

BENJAMIN, Walter. Magia e técnica, arte e politica.SP: Brasiliense, 1984.

BENJAMIN, Walter. A Origem do drama barroco alemão.SP: Brasiliense, 1984.

BENOIST, Luc. Signos, símbolos e mitos. BH: Interlivros, 1976.

BOSI, Alfredo. A Dialética da colonização. SP: Companhia das Letras, 1992.

BOSI, Alfredo. O Ser e o tempo da poesia. SP: Cultrix, 1983.

CÂNDIDO, Antonio. Literatura e sociedade. 5. ed. SP: Ed. Nacional, 1976.

CÉSAIRE, Aimé. Discurso sobre o colonialismo. Trad. Noêmia de Sousa. Lisboa: Sá da Costa, 1978.

CÉSAIRE, Aimé. Cabier d'un retour au pays natal. Paris: Présence Africaine, 1971.

CHABAL, Patrick. Vozes moçambicanas. Lisboa: Vega, 1994.

CHAUÍ, Marilena. (1991) “A Era dos simulacros". In: Jornal do Brasil. Caderno Idéias. Rio de Janeiro: 08-041991.p. 6.

COELHO, Teixeira. O que é utopia. 3. ed. SP: Brasiliense, 1981. (Coleção Primeiros Passos, 12)

COUTO, Mia. Cronicando. Lisboa: Ed. Caminho, 1991.

DAVIDSON, Basil. Mãe negra. Lisboa: Sá da Costa, 1978.

DAVIDSON, Basil. Os Africanos: uma introdução à sua história cultural. Lisboa: Ed. 70, 1981.

ERVEDOSA, Carlos. Roteiro da literatura angolana.Luanda:UEA,1983.

ESTUDOS PORTUGUESES E AFRICANOS. Campinas: IEL, UNICAMP, do número 73 ao 92 (19 volumes).

FANON, Frantz. Os Condenados da terra. Prefácio de Sartre. Trad. José Laurêncio de Melo. Rio: Civilização Brasileira, 1968.

FANON, Frantz. Pele negra, máscaras brancas. Rio: Ed. Fator, 1983.

FERREIRA, Manuel. No Reino de Caliban. 3. ed. Porto: Plátano, 1977. 3 vol.

FANON, Frantz. 50 poetas africanos. Lisboa: Ed. Plátano, 1989.

FANON, Frantz.Literaturas africanas de expressão portuguesa. SP:Ática, 1987.

FANON, Frantz.O discurso no percurso I. Lisboa: Plátano, 1989.

HABERMAS, J.Conhecimento e interesse. Rio de Janeiro: Ed. Zahar, 1980.

KI-ZERBÔ, Joseph. História da África negra. Lisboa: Europa - América, 1978. 2 v.

LABAN, Michel. Encontro com escritores. Porto: Fundação Engenheiro António de Almeida, 1989-1998. 3 volumes.

LABAN, Michel et alii. Luandino e sua obra: estudos, testemunhos, entrevistas. . Lisboa: edições 70, 1980.

LARANJEIRA, Pires. Literaturas africanas de expressão portuguesa. Lisboa: Universidade Aberta, 1995.

Légua \& meia: Rrvista dr litrpatura \& Divgrsidadr Cultural - 111 
LE GOFF, Jacques. A História nova. SP: Martins Fontes, 1990.

LE GOFF, Jacques. História e memória. Campinas: UNICAMP, 1990.

MARGARIDO, Alfredo. Estudos sobre literaturas das nações africanas de lingua portuguesa. Lisboa: A Regra do Jogo, 1980.

MATA, Inocência. Pelos trilhos da literatura africana em língua portuguesa. Ponte vedra /Braga, Cadernos do Povo,1992.

MATA, Inocência. Diálogo com as ilhas. Lisboa: Expo 8, 1998.

MIRABILIS de veias ao sol: antologia dos novíssimos poetas cabo-verdianos. Seleção e apresentação de José Luís Hopffer Almada. Lisboa: Caminho e Instituto Cabo-verdiano do Livro, 1991.

MEMMI, Albert. Retrato do colonizado precedido do retrato do colonizador. Rio: Paz e Terra, 1977.

MENDONÇA, Fátima. Literatura mosambicana: a história e as escritas. Maputo: Universidade Eduardo Mondlane, 1988.

MOSER, Gerald \& FERREIRA, Manuel. Bibliografia das literaturas africanas de expressão portuguesa. Lisboa: IN - CM, 1983.

MOURALIS, Bernard. As Contraliteraturas. Coimbra: Almedina, 1982.

MOURALIS, Bernard. Littérature et développement. Paris: Silex, 1984.

MUNANGA, Kabengele. Negritude: usos e sentidos. SP: Ática, 1986.

NEVES, João Alves. Poetas e contistas africanos. São Paulo: Editora Brasiliense, 1963.

NOBRE, Maria da Conceição. Antologia de poesias angolanas. Nova Lisboa: Serviços Culturais, 1957

NOVAES, Adauto (org.). Tempo e história. SP: Cia das Letras, 1992.

PADILHA, Laura Cavalcante. Entre voź e letra: o lugar da ancestralidade na ficção angolana pós-50. Niterói: EDUF, 1995.

PAZ, Octavio. Signos em rotação. SP: Perspectiva, 1976.

PAZ, Octavio. O Arco e a lira. 2. ed. Rio: Nova Fronteira, 1982.

PAZ, Octavio. Signos em rotação. São Paulo: Ed. Perspectiva, 1972.

PAZ, Octavio. Labirinto da solidão. Rio de Janeiro: Ed. Paz e Terra, 1984

PAZ, Octavio A Outra voz. Rio de Janeiro: Ed. Siciliano, 1993.

REDINHA, José. Distribuição étnica de Angola. Luanda: instituto de Investigação Científica de Angola, 1971. REIS, Carlos e LOPES, Ana Cristina. Dicionário de narratologia. Coimbra: Almedina, 1987.

REVISTA Range-Rede, 2, Ano 2. Rio : Fac. Letras da UFRJ, Setor de Publicações, 1996.

REVISTA Língua Mar: criações e confrontos em língua portuguesa. (Org. de Ana Maria Galamo). 2. ed. Rio: FUNARTE, 1997.

RIAÚZOVA, Helena. Dę anos de literatura angolana. Lisboa: Edições 70,1987.

ROSÁRIO, Lourenço. A Narrativa africana. Lisboa: Instituto de Cultura e Língua Portuguesa, Angolê, 1989.

ROUANET, Sérgio Paulo. Édipo e o Anjo. Rio: Tempo Brasileiro, 1981. p. 85 a 112.

SAID, Edward. Cultura e imperialismo. SP: Companhia das Letras, 1995.

SANTIAGO, Silviano. Uma literatura nos trópicos: ensaios sobre dependência cultural. SP: Perspectiva, 1978.

SANTILLI, Maria Aparecida. Africanidades. SP: Ática, 1985.

SANTILLI, Maria Aparecida.Estórias aficanas.SP:Ática,1985.

SANTOS, Boaventura de Sousa. Pela mão de Alice: o social e o político na pós-modernidade. 2. ed. São Paulo: Ed. Cortez, 1996.

SANTOS, Milton. A Natureza do espaço: técnica e tempo, razão e emoşão. 2. ed. SP: Huicitec, 1997.

SANTOS, Milton et alii [ Org.]. (1993) Fim de século e globalização. S P: Ed. Huicitec - Anpur. 
SARTRE, Jean-Paul. Orphée noir. In: SENGHOR, L.S. Antologie de la nowvelle poésie nègre et malgache de langue française. Paris: PUF, 1948.

SAÚTE, Nelson. Antologia da novíssima poesia moçambicana.Maputo: Aemo, 1993.

SCHAMA, Simon. Paisagem e memória. SP: Cia das Letras, 1996.

SECCO, Carmen Lucia Tindó.[Org.]. Guia Bibliográfico das literaturas africanas de língua portuguesa em Bibliotecas do Rio de Janeiro. Rio: UFRJ/UERJ,1996.( obra policopiada).

SECCO, Carmen Lucia Tindó. "No Ranger da memória e nas redes do poético: o processo de reinvenção verbal em Guimarães, Luandino Vieira e Mia Couto". In: Revista Range-Rede, n. 2, Ano 2. Rio : Fac. Letras da UFRJ, Setor de Publicações, 1996.

SECCO, Carmen Lucia Tindó [ Org. ]. Antologia do mar na poesia africana do século XX: Moçambique. Rio: UFRJ/UERJ, 1998. vol. 3. ( obra policopiada).

SENGHOR, L.S. Antologie de la nouvelle poésie nègre et malgache de langue française. Paris: PUF, 1948.

TENREIRO, Francisco José e M. P. de ANDRADE .Poesia negra de expressão portuguesa. Lisboa: Ed. África, 1982.

TRIGO, Salvato. Ensaios de literatura comparada afro-luso-brasileira. Lisboa, Vega:1986.

TRIGO, Salvato. Ensaios de literatura comparada afro-luso-brasileira. Lisboa: Vega, 1986.

TRIGO, Salvato. A Poética da Geração Mensagem. Porto: Brasília,1979.

WHITE, Eduardo. Poemas da ciência de voar e da engenharia de ser ave. Lisboa: Ed. Caminho, 1992.

TRIGO, Salvato. Os Materiais do amor seguido de O Desafio à tristeza. Lisboa: Ed. Caminho, 1996.

Carmen Lucia Tindó Secco é Doutora em Letras e Professora da Universidade Federal do Rio de Janeiro. Dedica-se aos estudos das Literaturas Africanas de Língua Portuguesa. 